\title{
ANALISIS MINAT BELAJAR DAN KEMAMPUAN AWAL KETERAMPILAN BERPIKIR KRITIS SISWA PADA MATERI MINYAK BUMI
}

\section{ANALYSIS OF LEARNING INTERESTS AND THE INITIAL ABILITY OF STUDENTS' CRITICAL THINKING SKILLS IN LEARNING PETROLEUM}

\author{
Eka Haryati, Yayuk Andayani", Syarifa Wahidah Al Idrus
}

Program Studi Pendidikan Kimia, FKIP Universitas Mataram, Indonesia

*Email: yayukmtr@unram.ac.id

\begin{abstract}
Abstrak: Penelitian ini bertujuan untuk mengetahui minat belajar dan kemampuan awal keterampilan berpikir kritis siswa pada materi minyak bumi di MAN 1 Mataram tahun ajaran 2018/2019. Jenis penelitian ini adalah penelitian non eksperimen dengan metode deskriptif. Populasi dalam penelitian ini meliputi seluruh siswa kelas XI MIA MAN 1 Mataram yang berjumlah 125 siswa. Teknik yang digunakan untuk pengambilan sampel yaitu dengan menggunakan teknik proportional random sampling. Sampel pada penelitian ini sebanyak 95 siswa. Pengumpulan data minat belajar menggunakan angket dan kemampuan awal keterampilan berpikir kritis siswa menggunakan tes. Teknik analisis data menggunakan statistik deskriptif. Teknik analisis data menggunakan interpretasi dan persentase. Hasil penelitian memperlihatkan bahwa minat belajar berada pada kategori sedang dengan persentase sebesar $66,32 \%$ dan kemampuan awal keterampilan berpikir kritis siswa termasuk dalam kategori sangat rendah dengan persentase sebesar $62,11 \%$. Pada indikator rasa tertarik berada pada kategori sedang dengan persentase sebesar $69,47 \%$. Pada indikator perhatian sebagian besar siswa berada pada kategori sedang dengan persentase sebesar $81,05 \%$. Pada indikator partisipasi sebagian besar siswa berada pada kategori rendah dengan persentase sebesar 58,95\% dan pada indikator keinginan/kesadaran sebagian besar siswa berada pada kategori sedang dengan persentase sebesar 68,42\%. Adapun pada indikator keterampilan berpikir kritis yaitu memberikan penjelasan sebagian besar siswa berada pada kategori sangat rendah dengan persentase sebesar $62,11 \%$. Pada indikator membangun keterampilan dasar sebagian besar siswa berada pada kategori sangat rendah dengan persentase sebesar 91,58\%. Pada indikator menyimpulkan sebagian besar siswa berada pada kategori sangat rendah dengan persentase sebesar 73,47\%. Pada indikator memberikan penjelasan lebih lanjut sebagian besar siswa berada pada kategori sangat rendah dengan persentase sebesar $89,47 \%$ dan pada indikator mengatur strategi dan taktik sebagian besar siswa berada pada kategori rendah dengan persentase sebesar $52,63 \%$.
\end{abstract}

Kata Kunci: Minat belajar, Kemampuan Awal Keterampilan Berpikir Kritis,

\begin{abstract}
Absctract: This study aimed to determine learning interests and the initial ability of students' critical thinking skill in learning petroleum at MAN 1 Mataram in academic year 2018/2019. This study is non-experimental research which applies descriptive methods. The population in this study covers the whole of students class XI MIA of MAN 1 Mataram which number 125 students. The technique used for sampling by using proportional random sampling technique. The samples of this study were 95 students. The data of the learning interest were collected using questionnaire and the data of the initial ability of students' critical thinking skills were collected using tests. The data were analyzed using descriptive statisticsin the forms of interpretations and percentages.The results of study showed that learning interests was in the medium category with a percentage of $66,32 \%$ and the initial ability of studens' critical thinking skill included in the very low category with a percentage of $62,11 \%$. The indicators of interest are in the medium category with a percentage of 69,47\%. Attention indicators are in the medium category with a percentage of $81,05 \%$. The indicator of participation is in the low category with a percentage of 58,95\% and the indicator of desire / awareness is in the medium category with a percentage of $68,42 \%$. As for the indicators of critical thinking skills that provide a simple explanation in the very low category with a percentage of $62,11 \%$. The indicators developing basic skills are in the very low category with a percentage of $91,58 \%$. The indicator concluding in the very low category with a percentage of $73,47 \%$. The indicators provide further explanation in the very low category with a percentage of $89,47 \%$ and the indicators set the strategy and tactics in the low category with a percentage of 52,63\% .
\end{abstract}

Key Words: Learning interests, Initial ability of students' critical thinking skills 


\section{PENDAHULUAN}

Perkembangan ilmu pengetahuan dan teknologi yang semakin pesat menyebabkan arus informasi menjadi cepat dan tanpa batas. Hal ini berdampak langsung pada berbagai bidang kehidupan, termasuk dalam bidang pendidikan. Proses pendidikan pun dituntut untuk menyiapkan serta menghasilkan Sumber Daya Manusia (SDM) yang berkualitas agar dapat memproses informasi tersebut dengan baik dan benar. Salah satu upaya dalam bidang pendidikan yang dapat dilakukan untuk mencetak SDM yang berkualitas yaitu dengan mengembangkan keterampilan berpikir kritis siswa [2].

Berdasarkan kajian yang dilakukan oleh sebuah lembaga yang bernama Partnership for 21st century skills, keterampilan berpikir kritis merupakan salah satu keterampilan esensi yang harus dimiliki oleh siswa. Keterampilan berpikir kritis juga dinyatakan sebagai salah satu modal dasar atau modal intelektual yang paling penting bagi setiap orang dan merupakan bagian yang fundamental dari kematangan manusia [13]. Seseorang yang memiliki keterampilan berpikir kritis mampu mengatur, menyesuaikan, mengubah, atau memperbaiki pikiran sehingga ia dapat bertindak lebih tepat [10]. Sejalan dengan pendapat tersebut, [7] juga mengungkapkan keterampilan berpikir kritis sangat diperlukan untuk mempersiapkan generasi muda yang mampu mengambil keputusan yang baik dan menjadi pemikir yang matang, sehingga mampu membawa bangsa ke arah yang lebih baik. Selain itu, keterampilan berpikir kritis sangat diperlukan untuk membantu menemukan dan menguasai suatu konsep.

Berdasarkan hasil studi Programme for International Student Assessment (PISA) tahun 2012, Indonesia berada di peringkat ke-64 dari 65 negara yang berpartisipasi dalam tes yang menunjukkan bahwa kemampuan berpikir siswa Indonesia rendah dibandingkan dengan negara lain di dunia. Hal ini dikarenakan beberapa negara maju telah mengembangkan sistem pendidikan yang mampu mengasah dan melatih kemampuan berpikir kritis siswa agar berkembang dengan baik [8].

Sebelum mengarah pada kegiatan meningkatkan keterampilan berpikir kritis siswa, hal pertama yang penting dilakukan adalah menganalisis kemampuan awal keterampilan berpikir kritis siswa. Kemampuan awal keterampilan berpikir kritis siswa diukur melalui suatu instrumen yang dikembangkan dengan mengacu pada indikator keterampilan berpikir kritis. Analisis kemampuan awal keterampilan berpikir kritis seharusnya dilakukan sebelum memulai pembelajaran.

Berdasarkan observasi yang dilakukan di MAN 1 Mataram melalui wawancara dengan guru mata pelajaran, diperoleh informasi bahwa guru belum pernah melakukan analisis kemampuan awal keterampilan berpikir kritis siswa dalam pelajaran kimia. Sebenarnya hal ini sangatlah penting untuk dilakukan sebagai upaya untuk memberikan gambaran dan informasi tentang bagaimana keterampilan berpikir kritis yang dimiliki siswa dan bagaimana upaya untuk memecahkan permasalahan yang didapatkan berkaitan dengan hal tersebut. Selain itu, guru dapat membantu mengembangkan keterampilan berpikir kritis tersebut dengan mengoptimalkan keterampilan berpikir kritis yang dimiliki siswa.

Salah satu faktor yang mempengaruhi kemampuan berpikir kritis antara lain minat belajar siswa. Minat terkait dengan perasaan ingin tahu, mempelajari, mengagumi, atau memiliki sesuatu [3]. Minat siswa untuk belajar kimia akan menentukan respon-respon yang akan diberikan oleh siswa tersebut terhadap hal-hal yang berkaitan dengan pembelajaran kimia. Siswa yang memiliki minat yang tinggi dalam mempelajari kimia cenderung memberikan respon positif terhadap pembelajaran kimia. Mereka akan cenderung memiliki inisiatif dan kemauan untuk mempelajari kimia lebih dalam dan meraih prestasi yang baik dalam pembelajaran kimia. Namun, kenyataan yang dihadapi di lapangan menunjukkan bahwa minat belajar kimia siswa bervariasi, yang dapat dikategorikan menjadi kelompok yang minat belajarnya rendah, sedang dan tinggi.

Perilaku yang menunjukkan adanya minat seseorang dalam belajar yaitu: ada rasa suka dan senang pada sesuatu yang diminati, mempunyai kecenderungan yang tetap untuk memperhatikan dan mengenang sesuatu yang dipelajari secara terus menerus, ada rasa ketertarikan pada aktivitas-aktivitas yang diminati, lebih menyukai suatu hal yang menjadi minatnya daripada yang lainnya serta ditunjukkan melalui partisipasi pada aktivitas dan kegiatan [11]. Adanya minat belajar cenderung mengakibatkan siswa bersedia untuk meninggalkan kegiatan yang kurang mendukung kegiatan belajarnya. Siswa dengan minat belajar akan berusaha lebih keras serta pantang menyerah dalam menghadapi tantangan dalam belajar [4].

kemampuan berpikir kritis adalah sebuah kondisi dimana siswa mampu menganalisis sebuah fakta, melakukan generalisasi dan mengorganisasikan ide untuk melakukan penyelesaian, mempertahankan ide tersebut, mampu membandingkannya untuk kemudian menguji argumennya dan menarik sebuah kesimpulan [9]. Seseorang dikatakan memiliki keterampilan berpikir kritis dapat dilihat dari beberapa indikator. Ennis (1996) mengungkapkan bahwa, ada 12 indikator berpikir kritis yang dikelompokkan dalam lima besar aktivitas [1], yaitu: 
1. Memberikan penjelasan sederhana, meliputi: memfokuskan pertanyaan, menganalisis argumen, bertanya dan menjawab pertanyaan.

2. Membangun keterampilan dasar, meliputi: mempertimbangkan kredibilitas suatu sumber, mengobservasi dan mempertimbbangkan hasil observasi.

3. Menyimpulkan, meliputi: membuat deduksi dan mempertimbangkan hasil deduksi, membuat induksi dan mempertimbangkan hasil induksi, membuat keputusan dan mempertimbangkan hasilnya, membuat keputusan dan mempertimbangkan hasilnya.

4. Memberikan penjelasan lebih lanjut, meliputi: mengidentifikasi istila-istilah dan definisi pertimbangan dan juga dimensi, mengidentifikasi asumsi.

5. Mengatur stategi dan taktik, meliputi menentukan tindakan, berinteraksi dengan orang lain.

\section{METODE PENELITIAN}

Penelitian ini telah dilakukan di MAN 1 Mataram pada semester I (Ganjil) tahun ajaran 2018/2019 yang terdiri dari 3 tahapan, yakni 1) Persiapan, 2) Pengumpulan Data dan 3) Pengolahan data hasil penelitian dan laporan. Penelitian ini merupakan jenis penelitian non eksperimen dengan metode deskriptif yang bertujuan untuk mendeskripsikan, menganalisis, dan mengambil suatu generalisasi dari pengamatan yang tidak mendalam mengenai minat belajar dan kemampuan awal keterampilan berpikir kritis.

Populasi penelitian ini yaitu seluruh siswa kelas XI MIA di MAN 1 Mataram yang berjumlah 125 siswa dan sampel penelitian sebanyak 95 siswa ditentukan dengan teknik Proportionate random sampling. Proporsional Random Sampling merupakan suatu teknik pengambilan sampel yang dilakukan secara proporsional dari setiap kelas yang ditentukan setimbang dengan banyaknya subjek dari masingmasing kelas [6]. Untuk menentukan jumlah sampel pada penelitian ini menggunakan rumus Isaac dan Michael. Penentuan siswa yang menjadi sampel dilakukan dengan mengundi masingmasing anggota populasi dari MIA prestasi sampai MIA 2 di MAN 1 Mataram. Jumlah siswa yang menjadi sampel penelitian ini pada kelas $\mathrm{X}$ MIA Prestasi sebanyak 31 siswa, kelas X MIA 1 sebanyak 32 siswa, dan kelas X MIA 2 sebanyak 31 siswa. Sehingga jumlah seluruh sampel pada penelitian ini sebanyak 95 sampel atau berjumlah $76 \%$ dari seluruh populasi.

Teknik pengumpulan data yaitu menggunakan soal essay yang berjumlah lima soal pada materi minyak bumi dan menggunakan kuesioner dimana terlebih dahulu dibuat instrumen yang telah diuji validitas serta reliabilitasnya. Selanjutnya, teknik analisis data yang digunakan analisis deskriptif.
Langkah-langkah yang dilakukan pada tahap analisis data yaitu, mentabulasi data tes kemampuan awal keterampilan berpikir kritis dan data angket minat belajar yang kemudian akan digunakan untuk menghitung persentase frekuensi kemampuan awal keterampilan berpikir kritis dan minat belajar.

\section{HASIL DAN PEMBAHASAN}

Hasil dari penelitian ini berdasarkan data hasil penyebaran soal dan angket. Jumlah siswa yang menjadi responden sebanyak 95 siswa. Berikut ini adalah hasil persentasi frekuensi minat belajar.

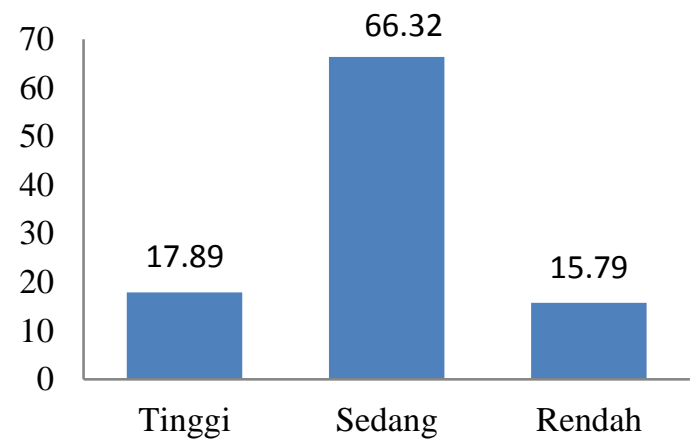

\section{Gambar 1. Persentase frekuensi minat belajar}

Berdasarkan grafik terlihat bahwa minat belajar siswa secara keseluruhan termasuk dalam kategori sedang, meskipun terdapat beberapa siswa yang memiliki minat belajar tinggi dan rendah. Hal ini menandakan bahwa masih belum optimalnya minat belajar siswa sehingga diperlukan adanya upaya meningkatkan minat belajar, misalnya dengan cara menyampaikan pelajaran secara menarik dan menyenangkan sehingga siswa menjadi lebih semangat untuk belajar, mengaitkan bahan pelajaran dengan peristiwa-peristiwa yang terjadi di lingkungan sekitar serta menguraikan kegunaannya bagi siswa di masa yang akan datang [11].

Berikut ini adalah hasil persentasi frekuensi minat beajar tiap indikator.

\section{Rasa Tertarik}

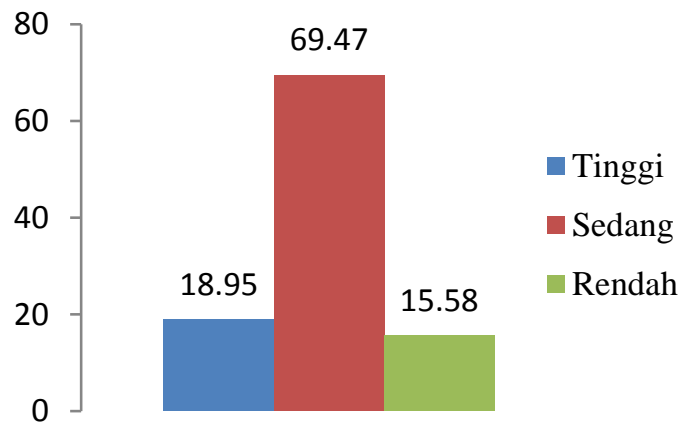

Gambar 2. Persentase Indikator Rasa Tertarik

Berdasarkan grafik terlihat bahwa pada indikator pertama yaitu rasa tertarik, diperoleh siswa yang memiliki rasa tertarik dengan kategori rendah 
sebanyak 11 orang atau 15,58\%, siswa yang memiliki rasa tertarik dengan kategori sedang sebanyak 66 orang atau $69,47 \%$, dan siswa yang memiliki rasa tertarik dengan kategori tinggi sebanyak 18 orang atau $18,95 \%$. Hal ini menunjukkan bahwa rasa tertarik terhadap pelajaran kimia yang dimiliki siswa berbeda-beda. Hal ini disebabkan oleh kurangnya penggunaan media dan alat-alat pembelajaran lainnya. penggunaan media pembelajaran dapat menimbulkan rasa tertarik dan mudah untuk menerima, mengerti dan memahami pelajaran yang akan dipelajari.

\section{Perhatian}

Pada indikator kedua yaitu perhatian, diperoleh siswa yang memiliki perhatian dengan kategori rendah sebanyak 9 orang atau 9,47\%, siswa yang memiliki perhatian dengan kategori sedang sebanyak 77 orang atau $81,05 \%$, dan siswa yang memiliki perhatian dengan kategori tinggi sebanyak 9 orang atau $9,47 \%$. Hal ini menunjukkan bahwa sebagian besar siswa memiliki perhatian terhadap pelajaran kimia.

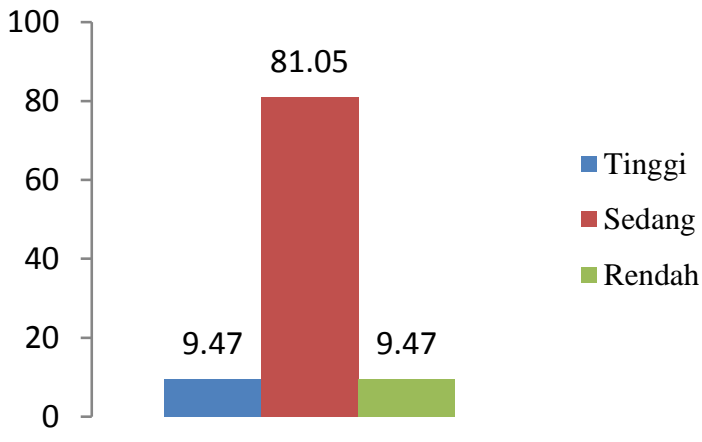

Gambar 3. Persentase Indikator Perhatian

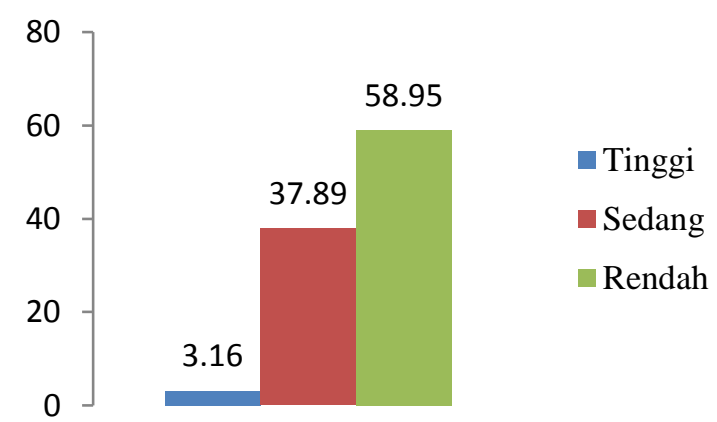

\section{Gambar 4. Persentase Indikator Partisipasi}

Perhatian dalam belajar sangat diperlukan, karena apabila siswa tidak memberikan perhatian terhadap apa yang mereka pelajari maka hasil belajar yang siswa peroleh akan rendah.

\section{Partisipasi}

Pada indikator ketiga yaitu partisipasi, diperoleh siswa yang memiliki partisipasi selama proses pembelajaran dengan kategori rendah sebanyak 56 orang atau 58,95\%, siswa yang memiliki partisipasi selama proses pembelajaran dengan kategori sedang sebanyak 36 orang atau $37,89 \%$, dan siswa yang memiliki partisipasi selama proses pembelajaran dengan kategori tinggi sebanyak 3 orang atau 3,16\%. Hal ini menunjukkan bahwa sebagian besar siswa kurang aktif berpartisipasi selama proses pembelajaran. Hal ini dapat diperlihatkan dengan sedikitnya siswa yang aktif bertanya, menjawab pertanyaan dari guru dan mengerjakan latihan yang diberikan. Partisipasi siswa dalam mengerjakan tugas kelompok dapat menambah pengetahuan siswa terhadap pelajaran yang sedang berlangsung. Hal ini dapat meningkatkan hasil belajar siswa karena siswa dapat ikut berpartisipasi dalam kegiatan pembelajaran.

\section{Keinginan/Kesadaran}

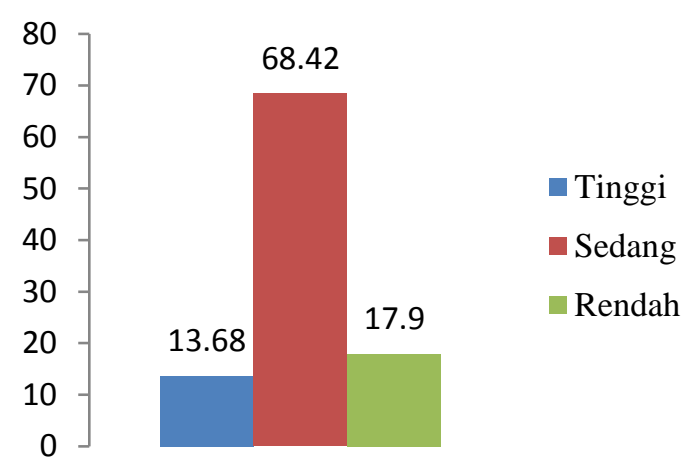

\section{Gambar 5. Grafik Persentase Indikator Keinginan/Kesadaran}

Pada indikator keempat yaitu keinginan/kesadaran, diperoleh siswa yang memiliki keinginan/kesadaran dengan kategori rendah sebanyak 17 orang atau 17,9\%, siswa yang memiliki keinginan/kesadaran dengan kategori sedang sebanyak 65 orang atau $68,42 \%$, dan siswa yang memiliki keinginan/kesadaran berprestasi dengan kategori tinggi sebanyak 13 orang atau $13,68 \%$. Hal ini menunjukkan bahwa keinginan/kesadaran siswa berbeda-beda antara siswa yang satu dengan lainnya. Sebenarnya keinginan/kesadaran sangat besar pengaruhnya terhadap hasil belajar, karena apabila siswa tidak memiliki keinginan/kesadaran untuk belajar, maka apa yang akan disampaikan pada materi pelajaran akan menjadi sia-sia. Hal ini sejalan dengan yang disampaikan oleh [13] bahwa minat berarti kecenderungan dan kegairahan yang tinggi atatu keinginan yang besar terhadap sesuatu. 
Adapun hasil persentasi frekuensi kemampuan awal keterampilan berpikir kritis.

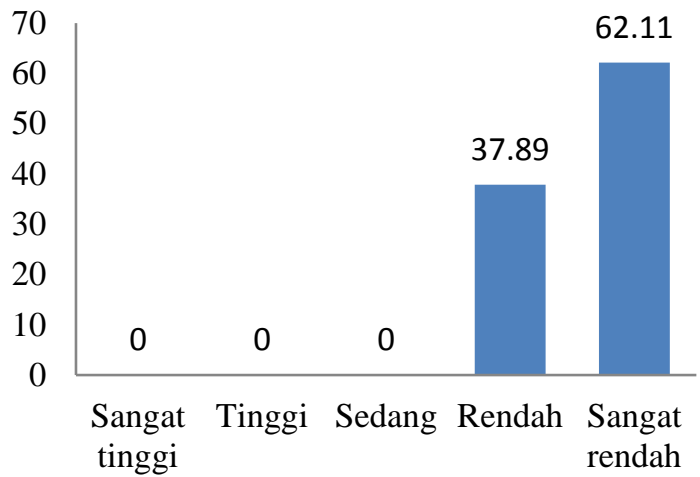

Gambar 6. Grafik Persentase frekuensi kemampuan awal keterampilan berpikir kritis

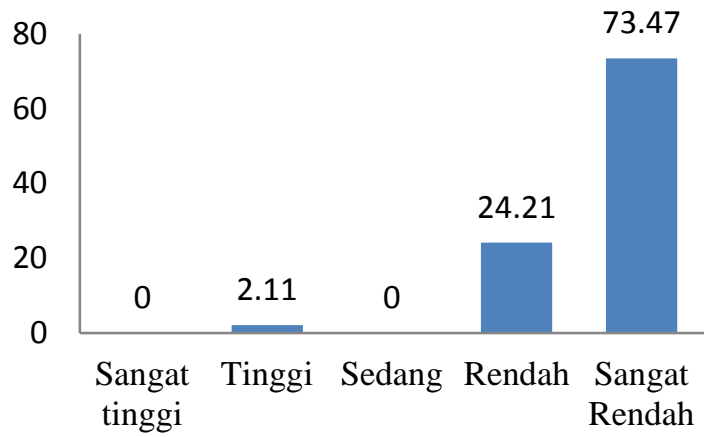

Berdasarkan grafik terlihat bahwa persentase frekuensi kemampuan awal keterampilan berpikir kritis siswa berada pada kategori sangat rendah. Hal ini menunjukkan bahwa masih banyak siswa yang memiliki kemampuan awal keterampilan berpikir kritis yang rendah. Salah satu penyebab rendahnya keterampilan berpikir kritis yaitu kurangnya minat baca siswa. Membaca akan membuat seseorang memiliki wawasan yang luas dan dapat menambah ilmu pengetahuan [14]. Pembelajaran yang diawali dengan membaca dapat membantu siswa membangun pengetahuannya sendiri dengan cara mengembangkan pengetahuan yang telah didapatkan sebelumnya melalui materi yang telah dibaca sebelum pembelajaran di kelas [5]. Rendahnya kemampuan awal keterampilan berpikir kritis tersebut menunjukkan bahwa perlu untuk dilakukan peningkatan keterampilan berpikir kritis siswa.

Berikut ini adalah hasil persentasi frekuensi kemampuan awal keterampilan berpikir kritis siswa tiap indikator.

\section{Memberikan penjelasan sederhana}

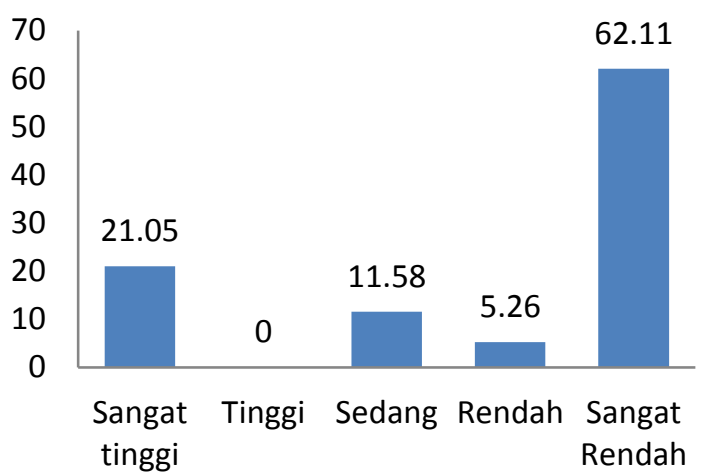

\section{Gambar 7. Grafik Persentase Indikator Memberikan Penjelasan Sederhana}

Pada indikator memberikan penjelasan sederhana, diperoleh siswa yang memiliki kemampuan memberikan penjelasan sederhana sebanyak 20 orang atau $21,05 \%$ dengan kategori sangat tinggi, tidak ada siswa yang berada pada kategori tinggi, 11 orang atau $11,58 \%$ dengan kategori sedang, 5 orang atau $5,26 \%$ dengan kategori rendah dan 59 orang atau $62,11 \%$ dengan kategori sangat rendah.

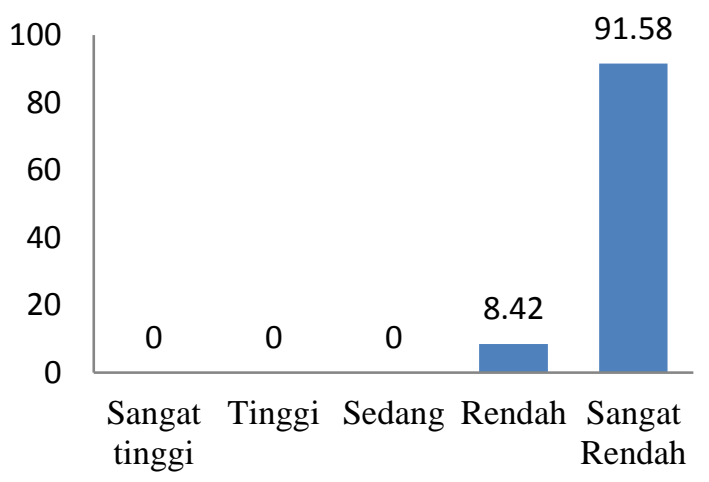

Membangun Keterampilan Dasar

Gambar 8. Grafik Persentase Indikator Membangun Keterampilan Dasar

Pada indikator membangun keterampilan dasar, diperoleh 8 siswa atau 8,42\% dengan kategori rendah, 87 siswa atau $91,58 \%$ dengan kategori sangat rendah dan tidak ada siswa yang berada kategori sangat tinggi, tinggi dan sedang.

\section{Memberikan Menyimpulkan \\ Gambar 9. Grafik Persentase Indikator Menyimpulkan}

Pada indikator menyimpulkan, diperoleh 2 siswa $(2,11 \%)$ dengan kategori tinggi, 23 siswa $(24,21 \%)$ dengan kategori rendah dan 70 siswa $(73,68 \%)$ dengan kategori sangat rendah dan tidak ada siswa yang berada pada kategori sangat tinggi dan sedang.

\section{Memberikan Penjelasan Lebih Lanjut}




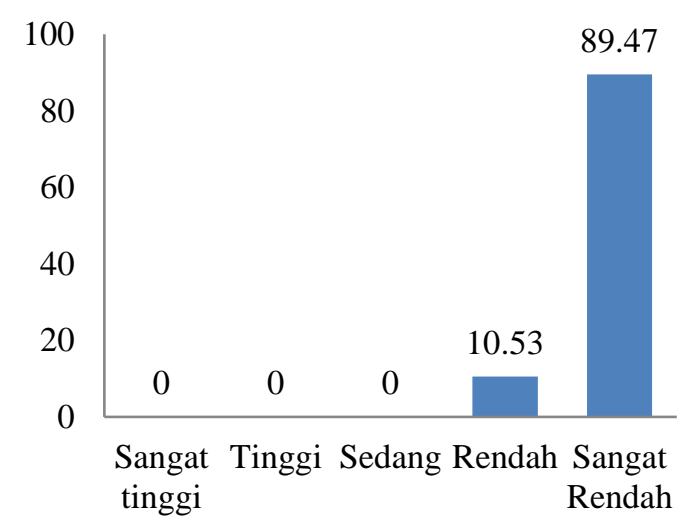

Gambar 10. Persentase Indikator Memberikan Penjelasan Lebih Lanjut

Pada indikator memberikan penjelasan lebih lanjut, diperoleh 10 siswa $(10,53 \%)$ dengan kategori rendah, dan 85 siswa $(89,47 \%)$ dengan kategori sangat rendah dan tidak ada siswa yang berada pada kategori sangat tinggi dan sedang.

\section{Mengatur Strategi dan Taktik}

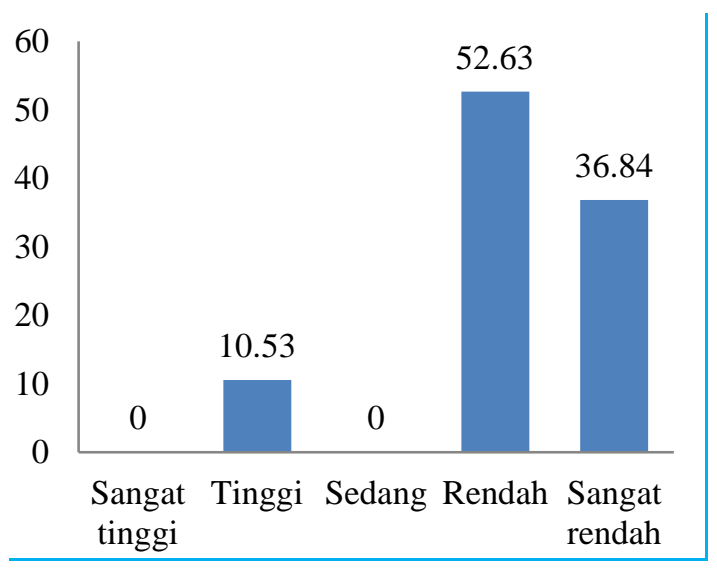

\section{Gambar 11. Persentase Indikator Mengatur Strategi dan Taktik}

Pada Indikator mengatur strategi dan taktik, diperoleh 10 siswa (10,53\%) dengan kategori tinggi, 50 siswa $(52,63 \%)$ dengan kategori rendah dan 35 siswa $(36,84 \%)$ dengan kategori sangat rendah dan tidak ada siswa yang berada pada kategori sangat tinggi dan sedang.

Berdasarkan uraian diatas, sekiranya guru perlu menumbuhkan keterampilan berpikir kritis siswa dalam proses pembelajaran. Sesuai dengan pendapat menurut Susanto (2013) menyatakan bahwa upaya untuk menumbuhkan kemampuan berpikir kritis siswa merupakan suatu kewajiban yang harus dilakukan guru dalam proses pembelajaran, guru harus dapat melahirkan cara berpikir yang kritis pada siswa. Guru dapat memberikan kesempatan dan dukungan kepada siswa untuk dapat menumbuhkan kemampuan berpikir kritisnya dengan memberikan metode pembelajaran yang sesuai diharapkan dapat membantu siswa menumbuhkan pengetahuan keterampilan nalar yang nantinya dapat berpengaruh pada keterampilan berpikir kritis [12].

\section{KESIMPULAN}

Berdasarkan data hasil penelitian dan pembahasan, maka dapat disimpulkan bahwa minat belajar sebagian besar siswa berada pada kategori sedang dan kemampuan awal keterampilan berpikir kritis sebagian besar siswa berada pada kategori sangat rendah.

\section{UCAPAN TERIMA KASIH}

Penulis menyadari penelitian ini tidak akan terselesaikan tanpa adanya bimbingan, arahan dan bantuan serta dukungan dari berbagai pihak. Oleh karena itu penulis mengucapkan terima kasih kepada: (1) Bapak kepala sekolah MA Negeri 1 Mataram yang telah memberikan izin penelitian dan (2) Bapak Khaerun Nasirin, S.Pd. selaku guru mata pelajaran kimia di MA Negeri 1 Mataram yang telah membantu dalam penyebaran angket siswa dan memberikan motivasi serta semangat sehingga penelitian ini terselesaikan tepat waktu.

\section{DAFTAR PUSTAKA}

1. Afrizon, R., Ratnawulan.,Fauzi, A. 2012. Peningkatan Perilaku Berkarakter dan Keterampilan Berpikir Kritis Siswa Kelas IX MTsN Model Padang Pada Mata Pelajaran IPAFisika Menggunakan Model Problem Based Instruction. Jurnal Penelitian Pembelajaran Fisika. 1(1): 1-16.

2. Zakrah, Z., Lestari, N., \& Kusmiyati, K. (2015). Pengaruh strategi pembelajaran discovery terhadap kemampuan berpikir kritis siswa pada mata pelajaran IPA kelas VIII di SMPN 3 Gunungsari tahun ajaran 2014/2015. Jurnal pijar MIPA, 10(2).

3. Rusydi, A. I., Hikmawati, H., \& Kosim, K. (2018). Pengaruh Model Learning Cycle 7E terhadap Kemampuan Berpikir Kritis Peserta Didik. Jurnal Pijar Mipa, 13(2), 124-131.

4. Rusydi, A. I., Hikmawati, H., \& Kosim, K. (2018). Pengaruh Model Learning Cycle 7E terhadap Kemampuan Berpikir Kritis Peserta Didik. Jurnal Pijar Mipa, 13(2), 124-131.

5. Djaali. 2014. Psikologi Pendidikan. Jakarta: Bumi Aksara.

6. Lestari, D. P. S., Sulastri, M., Margunayasa, I. G. 2016. Pengaruh Model Pogil dan Minat Belajar Terhadap Hasil Belajar IPA Pada Siswa Kelas V SD. e-Journal PGSD UniversitasPendidikan Ganesha Jurusan PGSD. 4(1): 1-10.

7. Mahakulkar, V., Wanjari, S. 2013. Assessing Reading Habits of B.Ed. Trainee Teachers. International Journal of Education and Psychological Research (IJEPR). 2(4): 99-105. 
8. Mulyatiningsih, E. 2011. Metode Penelitian Terapan Bidang Pendidikan. Yogyakarta: Alfabeta.

9. Nurafiah, F., Nurlaelah, E., Sispiyati, R. 2013. Perbandingan Peningkatan Kemampuan Berpikir Kritis Siswa SMP Antara yang Memperoleh Pembelajaran Means-Ends Analysis (MEA) dan Problem Based Learning (PBL). Jurnal Pengajaran MIPA. 18(1): 1-8.

10. OECD. 2013. Survey International Program for International Student Assessment (PISA). (Online) (http: // www.oecd.org/pisa), diakses pada tanggal 20 April 2018.

11. Rasiman, R. 2013. Meningkatkan Kemampuan Berpikir Kritis Melalui Pembelajaran Matematika Dengan Pendekatan Matematika Realistik. Aksioma, 4(2): 544-552.

12. Rasyida, N., Tapilouw, F.N., Priyandoko, D. 2015. Efektivitas Pengembangan Praktikum Virtual Untuk Meningkatkan Kemampuan Berpikir Kritis dan Sikap Ilmiah Siswa SMA Pada Konsep Metagenesis Tumbuhan Lumut dan Paku. Prosiding Seminar Nasional Pendidikan Biologi 2015. UMM Malang, 21 Maret 2015. 1663-1684.

13. Slameto. 2015. Belajar dan Faktor-Faktor yang Mempengaruhi. Jakarta: Rineka Cipta.

14. Sulistiani, E., Budiarti, R. S., Muswita. 2016. Analisis Kemampuan Berpikir Kritis Siswa Lintas Minat Pada Pembelajaran Biologi Kelas X IIS SMA Negeri 11 Kota Jambi. Biodik. 2(1): 13-19.

15. Syah, M. 2012. Psikologi Pendidikan dengan Pendekatan Baru, Bandung: Remaja Rosda Karya.

16. Purwoko, A. A. (2017). Pengaruh Model Pembelajaran Learning Cycle 7E Terhadap Hasil Belajar Kimia Ditinjau Dari Kemampuan Berpikir Kritis Siswa. Jurnal Penelitian Pendidikan IPA, 3(2). 